平成18年 3 月 10 日に開催し, 平成17年度事務・事業報告案, 平成17年度会計報告および決算見通し案, 平成18年度事業計画 案，平成18年度収支予算案の 4 件について，全て異議なく承認 した.

c. 企画推進委員会 (3 回)

平成17年 7 月28日，9月 1 日に開催し，平成17年度事業につ いて実施スケジュールの確認，実施状況の把握を行い，事業活 動の推進をはかった。平成18年 3 月 3 日, 次年度計画について の審議を行った。

d. 運営委員会 (4回うち 3 回は企画推進委員会と合同開催) 平成17年 7 月 28 日，9月 1 日，10月12日に開催し，平成17年 照明普及賞の選考に関わる審議，照明普及賞募集などに関わる 情報システム化の検討などを行った。

平成18年 3 月 3 日，平成17年照明普及賞の決定を行った。

(2) 会勢

平成16年度末 52 社（207.0口）

平成17年度末 50 社 (204.5口)

\section{2 .2 事業報告}

（1）優秀照明施設，照明普及功労者の表彰 平成 16 年完成の優秀照明施設, 普及功労者の選考, 表彰を実施. （全77件）平成17年 5 月27日表彰を行った。

(2)「あかりの日」キャンペーン

関係 3 団体と共催し，「あかりの日」キャンペーンを全国10地
区で実施し，リーフレット，電球を街頭配布した。

また，「第 6 回全国小学生ポスターコンテスト」も実施（応募 471点, 表彰111点) した。

(3) あかりのたよりの発行

普及部だより(バックナンバー)を学会ホームページ上にて公開 した.

(4) 定期刊行物の発行

○あたらしい照明

140 号「平成16年照明普及賞号」 3500 部 平成17年 5 月発行

141 号「光の風景 〜移り行く南かり2005〜」1550部 平成17 年11月発行

○新・照明教室

「オフィス照明〜省エネルギーと快適性を両立するために 〜」2300部 平成18年 2 月発行

(5) 特別刊行物の発行

「あかりの日」リーフレット 200500部 平成17年 9 月発行

（6）照明講習会への講師派遣

○照明設計技術セミナー（依頼元：雇用・職業開発機構）

平成17年10月13日 14日

（7）照明普及地区活動の推進 (各地区での講習会講演会などの実施) 各地区にて，学会支部活動と共同で実施.

（井上 岳・東京電力侏)）

\title{
12.3 日本照明委員会（日本，国際）の活動
}

\subsection{1 運営委員会の主な活動}

(1) 事業運営委員会 (渕田隆義委員長)

- 第13回（2005年6月27日）, 第14回（2006年 3 月 9 日）JCIE セ ミナーの開催を支援した。

- 第21回日本照明委員会大会（2005年 7 月13日）の開催を支援し た.

・第37回通常総会, 第15回 JCIE セミナー, 第22回日本照明委員 会大会などの準備を推進した。

(2) 技術運営委員会 (金谷末子委員長)

・CIEの各部会, 技術委員会およびレポータなどの活動状況の把 握とその対応, 国内委員会による技術活動の推進を中心に活動 した.

・第21回日本照明委員会大会特別講演とプログラムを企画立案し た。

・第13回 JCIE セミナー「博物館・美術館のあかり一展示空間の 演出と展示物の保護」を企画立案した.

- CIE 会長 van Bommel 氏来日記念講演会「光の視覚的効果と生 物学的効果一今後の研究課題と照明計画への展開一」を企画立 案した。

・第14回 JCIE セミナー「光がサポート “心と身体の健康”」を企 画立案した。

- 関連学協会と共同で 4 団体共同規格「照明用白色 LED 光源測 定方法通則 第 2 版」の発行に協力した.

\subsubsection{ISO/CIE 規格国内審議委員会（矢口博久委員長）}

2005年度事業計画に基づき, 委員会を 2 回開催し, 下記の審議 を行った。

・第 1 回委員会 (2005年10月18日)
CIE DS019.2/E "Photocarcinogenesis Action Spectrum (NonMelanoma Skin Cancer)" (非黒色腫型皮膚がんの光発ガン作用 スペクトル)に対する NC 投票にあたっての事前審議を行った. ・第 2 回委員会 (2006年 1 月16日)

CIE DS014-1.3/E "Colorimetry - Part 1 : CIE Standard Colorimetric Observers" (CIE 標準観測者) および CIE DS014-2.3/E "Colorimetry - Part 2: CIE Standard Illuminants"（CIE 標準イルミナント）に 対する $\mathrm{NC}$ 投票にあたっての事前審議を行った。

\section{3 .3 照明関連国際規格委員会 (矢口委員長)}

国際規格の整備，情報交換，日本提案型の国際規格推進を目的 とした照明関連団体の横断的委員会である，参加団体は，日本電 球工業会, 日本照明器具工業会, 照明学会, 日本色彩学会, 人間 工学会, 建築学会および日本照明委員会の 7 団体である。2005年 度は 3 回の委員会を開催した。また，標準化に向けた重点課題を 番議する「LED 光源の生体安全性規格化 WG（第 2 期）」, 「照明 光源（LEDを含む）の演色性評価方法WG」および「屋内作業 場の照明設計ガイドWG」を設置し，審議を開始した。

\section{$12.3 .4 \mathrm{JCIE}$ ホームページ委員会 (中村芳樹委員長)}

・委員会を15回開催し，ホームページをリニューアルした。

\section{3 .5 国内委員会の活動}

（1）第 1 部会「視覚と色」国内委員会 (中野靖久委員長)

- 平成17年 7 月 13 日, 金沢工業大学にて第 1 部会国内委員会を開 催した. TCl-48「CIE 出版物の15.2の改訂」によりまとめられ た CIE 15 (3rd edition) "Colorimetry" の翻訳作業を TCl-48国内 技術委員会で検討することになった。第 1 部会の今後の進路に ついて, 応用に目を向けたアプローチが必要との意見があった。

・照明用光源（LED を含む）の演色性評価方法 WG」が矢口会 
長を委員長として発足した. 現在, TCl-62「LED 光源の演色性」 で新しい演色評価方法に関する $\mathrm{TC}$ 設立の動きを受け，日本か らの提案を取りまとめる活動を行っている.

(2) 第 2 部会「光と放射の物理測定」国内委員会 (齊藤一朗委員長) 第21回日本照明委員会大会（金沢工業大学）において，2005年 5月16日〜 5月18日にスペインのレオンで開催された第 2 部会会 議ならびに技術委員会の動向を紹介した. その後, 国内委員会を 開催して第 2 部会国内委員会幹事を選出した.

（3）第 3 部会「屋内環境と照明設計」国内委員会 (古賀靖子委員長) CIE 出版物 157-2004「Control of Damage to Museum Objects by Optical Radiation：光放射による展示物の損傷の抑制」の翻訳出 版委員会を立ち上げ，JCIE 翻訳出版 No.15「博物館展示物の光放 射による損傷の抑制」を作成した。

(4) 第 4 部会「交通照明と信号」国内委員会 (斎藤孝委員長)

・ 2 回の国内委員会を開催した.

- 関連技術委員会の活動状況, および日本の対応について審議し, 特に TC4-36「道路照明の可視度設計」について成定康平委員 から，TC4-43「道路トンネルの非常時の照明」について斎藤 孝委員長からそれぞれ活動報告がなされた。

（5）第 5 部会「屋外及びその他の照明応用」国内委員会（川上幸 二委員長)

- 国内部会会議を 3 回開催し，各 TC に関する情報交換を行うと ともに，日本意見のとりまとめを行なった．

・TC5-19「非常照明」の部会投票について審議し, 賛成票を投 じることとした。

・TC5-11「カラーテレビジョン放送のためのスポーツ照明実用 設計ガイド」の原案の翻訳を行った。

・TC5-13「屋外作業場の CIE/ISO 規格」に関する CIE S015 と CIE S016の 2 つの CIE 規格を翻訳し, JCIE 翻訳出版 No.15「CIE 規格屋外作業場の照明基準」を刊行した.

(6) 第 6 部会「光生物学と光化学」国内委員会 (河本康太郎委員長)

·委員会を 3 回開催した.

・TC6-57「青色光網膜傷害および網膜の熱的傷害の作用スペク トルと関連用語の標準化」特別技術委員会 (河本康太郎委員長) では, 構成員間で分担して, 作用スペクトルの最近の試験デー 夕の收集と関連専門用語の抽出を行っている.

(7) 第 8 部会「画像技術」国内委員会（会津昌夫委員長）

・2005年12月に11名の委員を集め，国内委員会を開催した．2005 年11月に，アメリカ，アリゾナ州，スコッッデール市で開催さ れた学会と併催の部会会議抢よび技術委員会を中心に, TC8-01〜 TC8-08の活動報告と情報交換を実施した。

・TC8-03に関する国内技術委員会に関しては, JBMIA（社)ビジ ネス機会・情報システム協会）と協働して，ガマットマッピン グに関する評価データを収集して，TC8-03会合に提出してい る.

・スコッツデール市に打ける部会会議にて, TC8-09：Image Archiving, TC8-10 : Office lighting for imaging, および R8-07 : New Reportership on Chromatic Adaptation Transform in CIECAM02が新設することが部会レベルで決まったので，対応 を検討し，TC8-09はスコープがはっきりするまで会津委員長， 池上委員が委員登録をし，TC8-10に関しては，矢口会長が委 員登録をすることになった。

- CIE TC8-03は, ICC (Intetnational Color Consortium) からの要 請に応える形で，ガマットマッピングアルゴリズムの標準化に
関して, ICC と会合を持った.

12.3 .6 大会・セミナー活動

(1) 第21回日本照明委員会大会

• 日時：2005年 7 月13日（水）

- 場所 : 金沢工業大学

（2）第12回 JCIE セミナー「人体と太陽 UV 防御」

・日時：2005年 4 月23日（金）

・場所：日本教育会館（一ツ橋ホール）７階中会議室

(3) 第13回 JCIE セミナー「博物館・美術館のあかり一展示空間 の演出と展示物の保護」

・日時：2005年 6 月27日（月）

・場所：東京都庭園美術館 新館大ホール

(4) 第14回 JCIE セミナー「光がサポート“心と身体の健康”」

・日時：2006年 (平成18年) 3 月 9 日（木）

・場所：電力館 8 階ホール

(5) CIE 会長 van Bommel 氏 来日記念講演会「光の視覚的効果と 生物学的効果一今後の研究課題と照明計画への展開一」

・日時：2005年（平成17年）9月29日 (木)

・場所：きゅりあん(品川区立総合区民会館）７階イベントホール

12.3.7 国際活動

(1) JCIE の国際活動（矢口博久会長）

・ 中間大会（2005年 5 月13日〜 5 月21日）に参加

・スペイン・レオンにて開催された CIE 中間大会コンファレン スに, JCIEから12件の論文が発表された。

(2) CIE 規格案の審議, 投票

- CIE DS014-1.3/E "Colorimetry - Part 1 : CIE Standard Colorimetric Observers"に対し，賛成の NC 投票を投じた.

• CIE DS014-2.3/E "Colorimetry - Part 2 : CIE Standard Illuminants" に対し，賛成の $\mathrm{NC}$ 投票を投じた。

(3) $\mathrm{CIE}$ 本部および $\mathrm{NC}$ 活動への支援

-2007年 CIE 北京大会支援のため, 中国照明学会に金谷副会長 を派遣し，意見交換を行った。

- 照明学会国際活動委員会との連携により2007年 CIE 北京大会 への支援活動を開始した.

（4） CIE 第 1 部会「視覚と色」(中野靖久部会委員)

・2005年 5 月16日，スペインのレオンにおいて第 1 部会会議が開 催され，日本からは佐川，矢口，阿山，氏家，伊藤，中野の 6 名が参加した，新しい技術委員会が 2 つ設立され，内 1 つは日 本 (氏家) が委員長を務める。

(1)TCl-57 : "Colorimetry - Part4 : CIE1976L*a*b* colour space" の 部会投票に対して，日本から賛成の投票を行った.

(2)CIE TC1-37：「補助測光システム」(佐川賢委員長)：TCレポー 卜を委員長が準備中である.

(3)CIE TCl-30「視感効率関数」（池田光男委員長）：TCl-30は Rl-38に移行し, Chairman's report として早急にレポートをま とめる予定である。

(4)CIE TCl-46「等価輝度の概念と応用」(中野靖久委員長) : 現在, 第2次ドラフトを作成中である.

(5)CIE TCl-54「視覚応答の加齢変化」（佐川賢委員長）：視覚の 加齢変化を, 分光感度, 視力, コントラスト感度について既存 デー夕を集め，分析し，それをまとめた報告書が準備されてい る。一方, CIE の事務局に高歯者の照明方式を検討し, そのガ イドラインを作成するワーキンググループが設置された．本委 員会はそのグループと連携を取り，データなどを共有する。 
(6)CIE TCl-61「色のカテゴリーマップ」（石田泰一郎委員長）： 照度に応じた色カテゴリー領域を色空間上に記述することを目 的とした委員会である。現在は，色カテゴリーの実験データゃ 使用する色空間について検討中である.

(7)CIE R1-37「目だちの視野」（伊藤納奈レポータ）：現在までに 研究されている視野の様々な機能について調査し, 視野機能を いくつかのカテゴリーに分け, それぞれの概要について報告を 行った。

(8)CIE R1-19「異色明るさマッチングの個人差の分類法」（矢口博 久レポータ)：レポートの作成状況を報告した。2006年 5 月才 タワで開催予定の第 1 部会会議にレポートを提出し, 本レポー 夕は解散する予定である。

(5) CIE 第 2 部会「光と放射の物理測定」(齊藤一朗部会委員) ・第 2 部会会議と TC 会議が2005年 5 月16日〜 5 月18日にスペイ ンのレオンで開催された。第 2 部会会議の参加者は約 47 名. 日 本からは齊藤一朗部会委員（産総研）他 3 名が出席した。

(1)前回部会会議以後の作業状況 : CIE 国際照明用語の第 2 部会担 当分の改訂版作成作業がほぼ終了した. DS010 (CIE Standard for $\mathrm{V}(\lambda)$ and $\mathrm{V}^{\prime}(\lambda):$ ISO/CIE) ならびにDS014-2（Reformulation of CIE Standard Illuminants A and D65) を作成した.

(2)技術委員会の終了：TC2-35: V $(\lambda)$ および $\mathrm{V}^{\prime}(\lambda)$ の CIE 標準 (委員長 K.D.Mielenz, アメリカ)

(3)TC2-53の名称を「材料に対する多様な幾何学条件での測色」 から「特殊色彩効果を発現する材料に対する多様な幾何条件で の測色および評価指標」に変更した。

(4)技術委員会の解散 : 以下のレポータを解散した. R2-27 : 反射率, 透過率測定の ISO/CIE 規格（委員長 D.Rich, アメリカ)

R2-28: 測色計の分光応答度評価 (委員長 B.Kranicz, ハンガリー) R2-33：レーザプロジェクタの測定（委員長 K.Niall, カナダ)

(5)ISO/CIE 規格作成を目指した $5 つ$ TC の活動状況 :

TC2-35：V $(\lambda)$ および V' $(\lambda)$ の CIE 標準は, ISO23539:2005(E) /CIE S010/E : 2004"Photometry-The CIE System of Physical Photometry" を出版した.

TC2-40：照度計, 輝度計の特性記述は, 第 3 ドラフトょり進 行していない.

TC2-46 : LED の光度測定に関する CIE/ISO 規格は，第 6 ドラ フトを審議した，最終ドラフトを作成し， TC 投票を予定して いる.

TC2-56 : 再帰反射測定の CIE/ISO 規格は, TC 会議を開催した. TC2-57 : CIE S014-2の改定は, 報告なし.

(6) $\mathrm{CIE}$ 第 3 部会「屋内環境と照明設計」(古賀靖子部会委員) 2005年 9 月にドイツ・ベルリンにおいて部会会議が開催された. TC3-30「ライト・ガイド（光誘導パイプ）」による技術報告書 CIE 164：2005「ライトガイドの技術と応用」が出版され, TC3-33「照明計算プログラムの評価」，TC3-38「昼光ガイド・ システム」，TC3-40「屋内照明システムの保守」による技術報告 書のドラフトが，それぞれ部会投票にかかった。新たに， TC3-42「照明設計ガイド」, TC3-43「光と健康」が設置された.

•CIE R3-13（古賀靖子レポータ）：第 3 部会による用語集（第 9 章および第10章）の改訂案は，2004年に部会投票および理事会 投票にかかり，全て賛成票を得た。他部会からの用語集改訂案 も2004年末までに出揃ったが, その中の用語と定義の矛盾を解 消するため，2005年 5 月にスペイン・レオンにおいて国際協調
委員会が開催された。その結果, 以下を取り決めた：1）国際 照明用語集・第 5 版は, IEC（国際電気標準会議）と合同で出 版しない，2）国際照明用語集・第 5 版は 2 篇に分け，第 1 篇 には一般用語，第 2 篇には応用に関する用語を揭載する，3） 用語はアルファベット順で示す，4）国際照明用語集・第 5 版 は, 英語のみで出版する，5）必要な各国国内委員会は, 翻訳 出版を行える.

(7) CIE 第 4 部会「交通照明と信号」(斎藤孝部会委員)

2005年 5 月にスペインのレオンで開催された部会会議と以下の

5 つの関連技術委員会で, 報告書原案の審議などを進めた。

TC4-15 道路照明（Pub.30.2の改訂）」（委員長：S.Onaygil）

TC4-21「天文観測に対する公共照明の干渉」(委員長：M.Gillet) TC4-26「道路照明施設の測光量の測定システム」（委員長： G.Rossi)

TC4-40「再帰性反射の交通標識の要件」（委員長：P.Calson） TC4-43「道路トンネルの非常時の照明」（委員長：M.Gillet） また，以下の 3 つの関連技術委員会と 1 つのレポータが新設さ れた。

TC4-44「道路照明の保守・管理」（委員長：P.Hautala） TC4-45「自動車照明」（委員長：G.Draper） TC4-46「道路信号灯 $(300 \mathrm{~mm}) 」($ 委員長 : C.Andersen) R4-29「研究課題の整理」(レポータ：D.Stark）

・TC4-36 : 「道路照明の可視度設計」において, 成定康平委員が テクニカルレポートの第 8 章を執筆中である.

・TC4-43：田中敦子・斎藤孝両委員が「道路トンネルの非常時 の照明」の第 2 ドラフトの調査, およびドラフトに対する日本 からの意見を検討した。 また，田中敦子委員が2005年11月にボ ストンで開催された会議に参加し，日本からの意見と国内の関 連研究を報告した。ドラフトの骨子が定まる前に日本の意見を きちんと提案できたことは特筆すべき点である。

・TC4-46: 安藤正道委員が国内の信号灯法規を英訳して TC 委 員長に送付した。

（8） CIE 第 5 部会「屋外及びその他の照明応用」（川上幸二部会 委員)

スペイン・レオンで開催された部会会議および TC 会議に，川 上部会委員が出席した，新たな TCとして，TC5-22「屋外投光 照明器具のビームパターン」(S.Davis, アメリカ), TC5-23「屋 外施設に抢ける半円筒面照度使用のためのガイドライン」 (P.Rombauts, ベルギー) が設置され，それぞれ西村唯史（松下 電工），川上幸二（岩崎電気）を委員として推薦した。

・TC5-11：2005年 4月に再度部会投票に付され，2006年 1 月に CIE 169：2005として出版される予定である.

・TC5-13：「屋外作業場の CIE/ISO 規格」は, CIE S015 と CIE S016の 2つの CIE 規格として出版された.

・TC5-16：「民間財産のセキュリティ照明」の Draft4へ向け，顔 の視認性に関する研究などの国内の研究資料を送付した。

・TC5-19：2006年 1 月に CIE DS020.2として出版される予定であ る.

(9) CIE 第 6 部会「光生物学と光化学」（河本康太郎部会委員） 2005年 9 月にエクスレバンで部会会議が開催され，下記の諸議 題について審議・検討並びに今後の施策の決定を行った.

- CIE TC6-39：技術報告書第 2 次原案に対する久席 TC 委員の意 見・コメントの収集中である.

・TC6-57：最近の実験データ，および作用スペクトルのまとめ 
方について議論した.

・CIE R6-01：2007年 7 月の CIE 北京大会までに報告書を提出す る予定で資料収集・解析中である。

(10) CIE 第 8 部会「画像技術」(会津昌夫部会委員) 2005年11月12日にスコッツデール市で部会会議が開催された.

・TC8-01 : CIECAM02として TR が発行され, 本 TC は解散した.

-TC8-02：ピクトリアル画像の色差を評価するのにふさわしい 色差式はどういうものかの検討を行っている.

•TC8-03：入出力デバイス間の色域整合方式（GMA）の調査, 性能比較実験方法の TR の発行および 3 団体から実験報告書が 提出されている. 今年は, 今後の進め方について審議が行われ た.

- TC8-04：複数照明下での順応変換を求める手法を TR として 発行し, 本 TC は解散した。

- TC8-05：拡張色空間の評価方法に関する TRを発行し, TC の
解散が決まった。

・TC8-06：画像用語集の第一版という位置付けで，発行作業に 入ることが決まり，活動を終了した，

・TC8-07：「マルチスペクトラル・イメージング」は, 特に進展 はなし。

・TC8-08 : 目的を High Dynamic Range Imaging の技術領域に特 化することが決まり，それに伴い，名称を，“Spatial Appearance Models"から "Spatial Appearance Models for High dynamic range Images" に変更し, Terms of reference を再定義して投票を実施 し，日本を含む各国部会委員全員賛成で可決された。

・R8-05 (Image Appearance)：レポータの Mark Fairchild 氏から, 未完ながら中間報告の位置付けでレポートの提出があった.

• R8-06 (Result of CIECAM02)：レポータの Nathan Moroney 氏か ら口頭でレポートはまだ完了していない旨, 現状報告があった。

（小松原 仁・財)日本色彩研究所）

\section{照明学会誌原稿募集}

現在，学会誌は年13号発行されております。このうち 4 号は論文号，1号は年報号として発行され，残りの 8 号が特集号となっております.

その中で一般記事のみの学会誌の発行も企画いたしております。記事の種別は問いませんので, 皆様からの 積極的なご投稿をお待ちいたしております。

記事の種別：論説, 座談会, 技術総説, 資料, 施設報告, 解説, ミ二解説, 誌上討論, 研究室紹介, 会議報告,

寄書，会員の広場，やさしい照明技術，楽しいあかりのヒント，私の視点，支部だより

執 筆 要 領 :「寄稿のしおり（一般号・年報号）」(照明学会HPに掲載）をご参照下さい.

掲 載 号: 学会誌編集委員会で決定いたします。

申 込 先：テ101-0048 千代田区神田司町 2-8-4 吹田屋ビル 3 階

TEL : 03-5294-0101 FAX : 03-5294-0102

E-mail : ieijjour@sepia.ocn.ne.jp URL : http://www.ieij.or.jp/

原稿提出先: 社団法人照明学会 学会誌編集担当: 中村三七雄 